\title{
Effect of Foliar Silicic Acid on Growth, Nutrient Uptake and Blast Disease Resistance of Finger Millet (Eleusine coracana (L.) Gaertn.)
}

\author{
T. S. Sandhya ${ }^{1}$, N. B. Prakash ${ }^{1}$, A. Nagaraja ${ }^{2}$ and Y. A. Nanja Reddy ${ }^{3}$ \\ ${ }^{1}$ Department of Soil Science and Agricultural Chemistry, University of Agricultural Sciences, \\ Bangalore, India \\ ${ }^{2}$ Department of Plant Pathology, University of Agricultural Sciences, Bangalore, India \\ ${ }^{3}$ Department of Plant Physiology, University of Agricultural Sciences, Bangalore, India \\ *Corresponding author
}

\section{A B S T R A C T}

\begin{tabular}{|l|}
\hline Ke y w o r d s \\
Tropical dry land, \\
Ragi, Soluble \\
silicon, Genotypes, \\
disease tolerance, \\
Yield parameters
\end{tabular}

Finger millet or ragi is the primary food source for millions of people in tropical dry land regions of Africa and Asia. Two field experiments were conducted to study the genotypic variation for silicon accumulation and the effect of foliar applied silicic acid on growth, nutrient uptake and blast disease resistance of ragi. Study showed a significant varietal variation for $\mathrm{Si}$ accumulation with an average $\mathrm{Si}$ content of $1.67 \%$ in the above ground part. Out of the ten genotypes studied, highest Si content was found in RAU $8(2.46 \%)$ and lowest by $\mathrm{K} 7(1.03 \%)$. In general, the order of $\mathrm{Si}$ accumulation in ragi was followed as glumes $(1.5-3.9 \%)>$ straw $(1.6-3.1 \%)>$ grains $(0.18-0.38 \%)$. Foliar application of Silicic acid increased test weight, grain and straw yield significantly. Significant increase in grain yield and test weight was observed with $4 \mathrm{ml} \mathrm{L}^{-1}$ foliar silicic acid spray, whereas $2 \mathrm{ml} \mathrm{L}^{-1}$ increased straw yield. Application of $4 \mathrm{ml} \mathrm{L}^{-1}$ foliar silicic acid increased Si uptake to an extent of $54.6 \%$ over control. There was a significant increase in $\mathrm{Ca}$ and $\mathrm{P}$ content in straw and glumes with the application of silicic acid. Reduction in finger blast was significant with the application of 2 and $4 \mathrm{ml} \mathrm{L}^{-1}$ of silicic acid. Reduction in blast symptoms were to an extent of $69.8 \%$ in GPU 28, $53.75 \%$ in GPU 67 and by $50.4 \%$ in K 7. This is the first time reporting of $\mathrm{Si}$ content in finger millet and the response of crop to foliar Si treatment.

\section{Introduction}

Finger millet (Eleusine coracana (L.) Gaertn.) [F: Poaceae] also known as Ragi or African millet ranks fourth in importance among millets in the world after sorghum (Sorghum bicolor), pearl millet (Pennisetum glaucum) and foxtail millet (Setaria italica). Ragi is grown over 25 countries in the semi-arid and subtropics of Africa and Asia in about 4 mha, mainly under rain- fed condition. Under irrigated condition, the crop has a yield potential of 3- 4 tha $^{-1}$. Finger millet has superior nutritional qualities than that of rice and is on par with that of wheat (Gupta and Gupta 2013). 
It is a good source of methionine, cystiene and lycine. The seed coat of the millet is an edible component of the kernel, rich in minerals like calcium and iron. It is also reported to have phytochemicals, like dietary fiber $(18 \%)$ and polyphenols (2-3\%). These phytochemicals are reported to have many potential health beneficial properties in human, such as anti-inflammatory, antiviral, anticancer and platelet aggregation inhibitory activity (Chetan and Malleshi, 2007).

The high fiber content (non- starch polysaccharides) and anti-nutritional factors in ragi which are known to reduce plasma glucose level in hyperglycemic persons (Kumari and Sumathi, 2002). It is an outstanding subsistence food crop as ragi can be stored safely for several years without any insect damage, and has been a traditional component of farmers' risk avoidance strategy in the drought-prone areas. Moreover, the dry weight ratio of grain to crop residue is about 3:7, of which latter is an excellent source of fodder for livestock especially in dry season. Affected by a variety of diseases of which blast caused by Pyricularia grisea Sacc. is a major problem in ragi.

The beneficial effects of $\mathrm{Si}$ on stimulating plant growth have received increasing attention, particularly in plants subjected to both abiotic (e.g. drought, salt and metal toxicity) and biotic (e.g. plant diseases and pests) stresses. Species of Poaceae contain 1020 times the concentration of $\mathrm{Si}$ found in nonmonocotyledonous species (Ma et al., 2002; Richmond and Sussman, 2003; Hodson et al., 2005).

However, most of the research work with regard to $\mathrm{Si}$ and plant nutrition focuses on major crops like rice, wheat, maize and sugarcane. Though a crop of immense unexploited potential and tolerant to various biotic and abiotic stresses, Si accumulation or its role on growth of ragi has not been documented. In this regard a basic study was conducted to investigate the genotypic variation for $\mathrm{Si}$ accumulation in ragi and the effect of foliar applied Si on growth, nutrient uptake and blast disease resistance in ragi.

\section{Materials and Methods}

The field studies were conducted in the experimental plots of Zonal Agricultural Research Station, Bangalore (Central Dry Zone, Karnataka). Soil was slightly acidic (pH 5.7), sandy clay in texture, with medium available Si content (Narayanaswamy and Prakash, 2009) of $70.5 \mathrm{ppm}$ and high in organic carbon content $9 \mathrm{~g} \mathrm{~kg}^{-1}$.

\section{Genotype screening for $\mathrm{Si}$ accumulation in ragi}

A field experiment was conducted with 10 popular ragi genotypes (Table.1) viz., GPU 28, GPU 67, GPU 48, GPU 66, Indaf- 9, Indaf- 5, RAU 8, VL 149, K 7, MR- 2.Of these genotypes, RAU 8, GPU 28, GPU 48, MR 2, GPU 66 are resistant; GPU 67 and Indaf 5 are moderately resistant and $\mathrm{K} 7$ is highly susceptible to blast disease. The experiment was laid out in randomized block design, with three replications. All the recommended management practices were followed and major nutrients were applied at the rate of @ 50: 40: $25 \mathrm{Kg} \mathrm{N}, \mathrm{P}_{2} \mathrm{O}_{5}, \mathrm{~K}_{2} \mathrm{O}$ ha $^{-}$ 1. The sources for $\mathrm{N}, \mathrm{P}$ and $\mathrm{K}$ were urea, single super phosphate and potassium chloride respectively. Plant sampling was done at harvest. Grains, glumes and straw were separated and dried at $70{ }^{\circ} \mathrm{C}$ until it reached constant weight. The dry matter was powdered and acid digested $\left(7 \mathrm{ml} \mathrm{HNO}_{3}: 2 \mathrm{ml}\right.$ $\mathrm{H}_{2} \mathrm{O}_{2}$ : $1 \mathrm{ml} \mathrm{HF}$ ) at $150{ }^{\circ} \mathrm{C}$ in a microwave. Digested samples were used for the determination of Si content, as described by Ma et al., (2002). 
To study the effect of silicic acid on growth, nutrient uptake and blast disease resistance

Another field experiment was conducted with three ragi genotypes, which varied in the level of resistance to blast disease; GPU 28 (resistant), GPU 67 (moderately resistant) and K 7 (highly susceptible). The experiment was set up in randomized block design with three replication as a $3 \times 3$ factorial, which included three levels of silicic acid $\left(0,2\right.$ and $\left.4 \mathrm{ml} \mathrm{L}^{-1}\right)$ and three genotypes.

Concentrated soluble silicic acid $\left(\mathrm{OSAB}_{3}{ }^{\circledR}\right)$ obtained from Silife Ltd., Leusden, The Netherlands, was used for spraying at 21 and 36 days after sowing. This silicon formulation contained $2 \% \mathrm{Si}$ as silicic acid, $1.2 \% \mathrm{~K}$ as $\mathrm{KCl}$ and $0.8 \% \mathrm{~B}$ as $\mathrm{H}_{3} \mathrm{BO}_{3}$.

Observations like plant height and number of tillers, peduncle length, test weight, grain and straw yield were recorded. Since the occurrence of the disease was common in Kharif season (June- August), the crop was allowed to have natural disease incidence. Disease incidence for finger blast in all the nine treatments was assessed using standard percentage scale method.

For elemental analysis, straw and heads were harvested from each plot separately at maturity and hand threshed to separate grain and glumes. Collected samples were acid digested and analyzed for various nutrients.

\section{Statistical analysis}

Data obtained were analyzed by ANOVA using SPSS software. Statistical differences among treatments were determined using least significant difference at 0.05 probability level. Disease incidence score was correlated with levels of silicic acid applied to study the effect of Si on blast resistance in Ragi.

\section{Results and Discussion}

\section{Genotypic variation in ragi for $\mathrm{Si}$ accumulation}

The study showed significant variation for $\mathrm{Si}$ accumulation between the ragi genotypes. Average Si accumulation in the above ground parts (Fig. 1), of different genotypes followed the trend, K7 < GPU $67 \leq$ Indaf $9=$ MR $2 \leq$ GPU $28=$ Indaf $5 \leq$ GPU $66 \leq$ GPU $48 \leq$ VL $149<$ RAU 8, with an average Si content of $1.67 \%$. In the screened genotypes, highest accumulation of silicon in the aboveground biomass $(2.46 \%)$ was noticed in RAU 8.

There was a significant variation in the $\mathrm{Si}$ content in different plant parts of ragi with glumes accumulating higher and grains with least $\mathrm{Si}$ irrespective of all genotypes. The average content of $\mathrm{Si}$ in glumes, straw and grain were $2.91,1.87$ and $0.23 \%$ respectively. Among the genotypes, $\mathrm{Si}$ accumulation for glumes was low for K 7 (1.46\%) which was on par with that of GPU $67(1.62 \%)$ and highest for RAU $8(3.93 \%)$. The Si content of different genotypes in glumes was in the order of $\mathrm{K} 7 \leq$ GPU $67<$ Indaf $5 \leq$ MR $2 \leq$ GPU 28 $\leq$ VL $149 \leq$ Indaf $9 \leq$ GPU $66 \leq$ GPU $48<$ RAU 8 and in straw, Indaf $9 \leq$ GPU $48 \leq$ GPU $66 \leq \mathrm{K} 7 \leq$ GPU $67<$ MR $2 \leq$ GPU $28<$ Indaf $5 \leq \mathrm{VL} 149<$ RAU 8. All the genotypes accumulated very less amount of $\mathrm{Si}$ in grains when compared to that of straw and glumes. The Si content ranged from 0.14 (K 7) to 0.38 $\%$ (RAU 8).

\section{Effect of silicic acid on growth and yield parameters}

There was a significant variation in the plant height with the application of foliar Si in ragi. At the time of harvest, plants of GPU 28, GPU 67 and $\mathrm{K} 7$ treated with 2 and $4 \mathrm{ml} \mathrm{L}^{-1}$ showed a reduction in height than the control (Table.1). 
Although there was increase in tiller number, it was not significant with the application of 4 $\mathrm{ml} \mathrm{L}^{-1}$ of foliar Si. Peduncle length reduced with the application of $4 \mathrm{ml} \mathrm{L}^{-1} \mathrm{Si}$ and was more prominent in GPU 28.

Application of foliar $\mathrm{Si}$ increased the grain yield, test weight and straw yield in all the genotypes (Table 1). GPU 28 and $\mathrm{K} 7$ responded to both levels of foliar $\mathrm{Si}$ application and showed significant increase in grain yield at $4 \mathrm{ml} \mathrm{L}^{-1}$ over the control.

\section{Effect of silicic acid on Si, P, Ca nutrition}

Application of foliar $\mathrm{Si}$ increased the $\mathrm{Si}$ content in all the genotypes (Table.2). Application of $4 \mathrm{ml} \mathrm{L}^{-1}$ of foliar Si obtained highest $\mathrm{Si}$ content $(2.45 \%)$. Though the $\mathrm{Si}$ accumulation in glumes was highest for GPU 28 in all the treatments, with the increased application of foliar $\mathrm{Si}, \mathrm{K}-7$ was also able to accumulate appreciable amount of $\mathrm{Si}$ in glumes. Similar observations were made with average Si content in straw, the highest being in GPU 28 (1.98\%). The Si content in grains showed an increase with the application of foliar $\mathrm{Si}$, but was significant only for $\mathrm{K}-7$ at $4 \mathrm{ml} \mathrm{L}^{-1}(0.26 \%)$. In general, $\mathrm{Si}$ content in grains at $4 \mathrm{ml} \mathrm{L}^{-1}$ treatment $(0.35 \%)$ was on par with control treatment in all the genotypes. There was a gradual increase in $\mathrm{Si}$ uptake with the increased application of foliar $\mathrm{Si}$. The total crop uptake was about $140.74 \mathrm{~kg}$ $\mathrm{ha}^{-1}$ at $4 \mathrm{ml} \mathrm{L}^{-1}$.

Application of foliar Si increased the $\mathrm{Ca}$ and $P$ content in straw and its uptake significantly and was highest in $4 \mathrm{ml} \mathrm{L}^{-1}$ in all genotypes (Table. 3). K 7 showed increase of Ca content from $0.74 \%$ in control to $1.13 \%$ at $4 \mathrm{ml} \mathrm{L}^{-1}$.

\section{Effect of silicic acid on blast disease incidence of ragi}

Among the genotypes, K 7 was highly infected with finger blast compared to other two genotypes. Though the rate of silicic acid had a significant and linear effect on reducing finger blast in all the three varieties, the effect was most conspicuous in $\mathrm{K} 7$. In all the three genotypes, application of $4 \mathrm{ml} \mathrm{L}^{-1}$ foliar silicic acid achieved highest control of finger blast (Fig. 2).

\section{Genotypic variation in ragi for $\mathrm{Si}$ accumulation}

The study showed significant variation for $\mathrm{Si}$ accumulation among the ragi genotypes (Fig. 2). Accumulation of $\mathrm{Si}$ in the above ground plant part was found to be in the order of K7 $<$ GPU $67 \leq$ Indaf $9=$ MR $2 \leq$ GPU $28=$ Indaf $5 \leq$ GPU $66 \leq$ GPU $48 \leq$ VL $149<$ RAU 8. Content of $\mathrm{Si}$ in the ragi genotypes varied from 1.1- $2.5 \%$ with an average of $1.67 \%$. In the screened genotypes, highest accumulation of $\mathrm{Si}$ in the above biomass (2.46 $\%$ ) was noticed in RAU 8 (Fig. 2). Marschner (1995) reported that dryland species of Gramineae, like wheat and sugarcane contain 1-3 \% $\mathrm{SiO}_{2}$. Similar results regarding the variation in $\mathrm{Si}$ accumulation in genotypes of some crop species have been reported; Japonica rice varieties have higher $\mathrm{Si}$ concentration than indica rice varieties and $\mathrm{Si}$ content in rice straw ranges from 4- $20 \%$ (Winslow et al., 1997; Hodson et al., 2005). Concentration of Si in sugarcane shoot varied with the variety and ranged from 0.64 to 1.02 $\%$ (Deren, 2001).

Perusal of the data showed a significant difference in accumulation of $\mathrm{Si}$ among glumes, straw and grain of ragi. Highest $\mathrm{Si}$ accumulation was in the glumes $(2.91 \%)$, followed by straw (1.87\%) and least in grains $(0.23 \%)$ irrespective of all genotypes. The $\mathrm{Si}$ content of different genotypes in glumes was in the order of $\mathrm{K} 7 \leq \mathrm{GPU} 67<$ Indaf $5 \leq \mathrm{MR}$ $2 \leq$ GPU $28 \leq$ VL $149 \leq$ Indaf $9 \leq$ GPU $66 \leq$ GPU $48<$ RAU 8 and in straw,Indaf $9 \leq$ GPU $48 \leq \mathrm{GPU} 66 \leq \mathrm{K} 7 \leq \mathrm{GPU} 67<\mathrm{MR} 2 \leq \mathrm{GPU}$ $28<$ Indaf $5 \leq$ VL $149<$ RAU 8 (Fig. 2). 
Similar to glumes of ragi with an average $\mathrm{Si}$ content of $2.91 \%$, Hodson and Sangster (1988) reported high silicification in the inflorescence bract of wheat (lemma and glumes) especially in the outer epidermal walls. Also in barley, $\mathrm{Si}$ content in grains ranged from $0-0.38 \%$ and more than $80 \%$ of total Si (1.5- $2.7 \%)$ was localized in the hull (Ma et al., 2003), Gallo et al., (1974) also noted that rice, oat, rye and wheat seed coat accumulated most of the silica and the grains least. After the uptake, $\mathrm{Si}$ is transported to the shoot passively, via the transpiration stream and is deposited as amorphous silica after the water evaporates at the termini of the transpiration stream. In many plants since the trichomes are the termini and with larger surface area, are site of prominent silicification (Epstein 1994, Epstein 2001). Likewise, glumes are the end of transpiration stream in ragi and hence high $\mathrm{Si}$ accumulation can be expected in these tissues.

\section{Effect of foliar Silicic acid on growth and yield parameters}

In the present study plants of GPU 28, GPU 67 and $\mathrm{K} 7$ treated with 2 and $4 \mathrm{ml} \mathrm{L}^{-1}$ showed a reduction in height than the control (Table. 1). Peduncle length also reduced with the application of $4 \mathrm{ml} \mathrm{L}^{-1} \mathrm{Si}$ and was more prominent in GPU 28. Many researchers observed that application of Si increased plant height, leaf area and dry mass of crops under flooded and even under drought conditions (Gong et al., 2003; Ma et al., 1989).

Application of foliar silicic acid increased the grain yield, test weight and straw yield in all the genotypes (Table.1). GPU 28and K 7 responded to both levels of foliar silicic acid and showed significant increase in grain yield at $4 \mathrm{ml} \mathrm{L}^{-1}$ over the control. Prakash et al., (2011) also noticed a significant increase in straw and grain yield in rice with foliar silicic acid over control. Though many studies reveal the benefits of $\mathrm{Si}$ in crop yield, most of them were with soil applied Si (Singh et al., 2006; Ma et al., 1989).

It is possible that, the reduction in the plant height might have improved the erectness of the plant and improved canopy structure during the grain filling stage and thereby promoted the translocation of photosynthates to the grains and increased 1000 seed weight (Table.1). Silicon is reported to improve the erectness of leaves and plant architecture thereby enhancing photosynthetic efficiency (Epstein 1994, Hattori et al., 2005). It has also been reported to be effective in preventing lodging in rice by increasing the thickness of the culm wall and the size of the vascular bundles thereby enhancing the strength of the stem (Prakash et al., 2011; Korndorfer et al., 2004).

\section{Effect of silicic acid on $\mathrm{Si}, \mathrm{K}, \mathrm{P}, \mathrm{Ca}$ nutrition}

Foliar application of silicic acid increased the $\mathrm{Si}$ content in all the genotypes (Table.2).Application of $4 \mathrm{ml} \mathrm{L}^{-1}$ of Silicic acid recorded highest Si content (2.45\%). Though the $\mathrm{Si}$ accumulation in glumes was highest for GPU 28 in all the treatments, with the increased application of foliar Silicic acid, K 7 was also able to accumulate appreciable amount of $\mathrm{Si}$ in glumes $(80 \%$ increase at $4 \mathrm{ml}$ $\mathrm{L}^{-1}$ over control). Similar observation was made with average Si content in straw, the highest being in GPU 28 (1.98 \%). The Si content in grains increased with the application of silicic acid, but was significant only for $\mathrm{K} 7$ at $4 \mathrm{ml} \mathrm{L}^{-1}(0.26 \%)$. There was a gradual increase in $\mathrm{Si}$ uptake with the increased foliar application of silicic acid. The total crop uptake was about $140.74 \mathrm{~kg} \mathrm{ha}^{-1}$ at $4 \mathrm{ml} \mathrm{L}^{-1}$ which was about $54.6 \%$ increase over control (91.04 $\left.\mathrm{kg} \mathrm{ha}^{-1}\right)$. Buck et al., (2008) and Guevel et al., (2007) reported that 
there was negligible or inconsistent absorption of foliar applied silicic acid. In the present study, silicic acid formulation was applied twice @ $2 \mathrm{ml} \mathrm{L}^{-1}(0.4 \mathrm{mM})$ and $4 \mathrm{ml}$ $\mathrm{L}^{-1}(0.8 \mathrm{mM})$, during the vegetative growth stages of the crop. Even though, the entire $\mathrm{Si}$ taken up by the plant cannot be justified with the relatively small amount of $\mathrm{Si}$ supplied through the leaves, there was a significant increase in Si content in all the above ground plant parts as well as $\mathrm{Si}$ uptake, with the silicic acid treatment. Therefore the effect of foliar application of silicic acid cannot be overlooked. The experimental soil had a medium content (70.47 ppm) of plant available Si (Narayanswamy and Prakash, 2009)

Application of foliar silicic acid increased the $\mathrm{Ca}$ and $\mathrm{P}$ content in straw and its uptake significantly and was highest in $4 \mathrm{ml} \mathrm{L}^{-1}$ in all genotypes (Table 3). Though the spray solution contained small amount of $\mathrm{KCl}(1.2$ $\%)$ and $\mathrm{H}_{3} \mathrm{BO}_{3}(0.8 \%)$, there was no significant increase in their content in plant tissue (data not presented).

The interaction of $\mathrm{Si}$ on the uptake of other mineral elements by rice plants have been studied in soil and hydroponics. More calcium will be taken up by the plant in the presence of plant available silicon, if there is adequate calcium in soil (Bent 2014). Islam and Shaha (1969) in rice and Lux et al., (2002) in sorghum reported that $\mathrm{Si}$ application promoted the uptake of $\mathrm{P}, \mathrm{Ca}$ and $\mathrm{Mg}$ and decreased the uptake of K. Ma et al., (1989) noted significant increase in shoot dry weight with increased application of $\mathrm{P}$ when $\mathrm{Si}$ was applied suggesting $\mathrm{Si}$ application raised the optimum P level in rice. Singh et al., (2006) found that $180 \mathrm{~kg} \mathrm{ha}{ }^{-1}$ of $\mathrm{Si}$ increased nitrogen and phosphate levels in the grain and straw of rice and suggested that $\mathrm{Si}$ applied at lesser amounts can be beneficial in increasing grain yield and growth of cereal crops.

\section{Effect of silicic acid on blast disease incidence of ragi}

Application of silicic acid significantly reduced the finger blast in all three varieties. Among the genotypes, K 7 was highly infected with finger blast and there was a reduction of $50.4 \%$ disease symptom with the application of foliar silicic acid (Fig. 2).

Application of $4 \mathrm{ml} \mathrm{L}^{-1}$ of foliar silicic acid decreased the disease infestation to an extend of $69.8 \%$ and $53.75 \%$ in GPU 28 and GPU 67. This may be attributed to the physical role of $\mathrm{Si}$ deposited in the glumes and fingers. Buck et al., (2008) found similar results as in Figure 2 with foliar application of silicic acid on blast disease of rice. Although, the silicic acid was applied during vegetative stage, the effective performance in terms of reduction in disease infestation was observed during the grain filling stage.

Increased uptake of $\mathrm{Si}$, its accumulation in glumes (Table 2) and the reduction of disease infestation support the fact that foliar applied Silicic acid was absorbed and stimulated the plant vigor imparting the plant with disease resistance. However, the mechanism by which $\mathrm{Si}$ provides protection against fungal plant pathogens in ragi is still unclear.

Some authors agree that $\mathrm{Si}$ acts as a physical barrier in cell walls, preventing the penetration of fungal hyphae into host tissues (Carver et al., 1987; Bowen et al., 1992; Datnoff et al., 1997), while others believe Si is related to specific plant defense reactions. Studies with regard to wheat and rice blast indicated that these species were capable of inducing biologically active defense agents, including increased production of glycosylate phenolics and antimicrobial products like diterpenoid phytoalexins (Fawe et al., 1998, Bélanger et al., 2003; Rodrigues et al., 2003). 
It was also reported that the epidermal cells of Si-treated plants reacted to pathogens with specific defense reactions, including papilla formation, production of callus and release of glycosylated phenolics (Bélanger et al., 2003;

Rodrigues et al., 2004).

Table.1 Effect of foliar application of silicic acid on growth and yield parameters of different ragi genotypes

\begin{tabular}{|c|c|c|c|c|}
\hline Parameters & Si levels & GPU- 28 & GPU- 67 & K- 7 \\
\hline \multirow[t]{3}{*}{ Peduncle length $(\mathrm{cm})$} & $0 \mathrm{ml} \mathrm{L}^{-1}$ & $28.86 b$ & $15.56 a$ & $23.86 b$ \\
\hline & $2 \mathrm{ml} \mathrm{L}^{-1}$ & $26.56 b$ & $14.47 a$ & 22.19ab \\
\hline & $4 \mathrm{ml} \mathrm{L}^{-1}$ & 23.35a & $13.55 a$ & 21.07a \\
\hline \multicolumn{5}{|l|}{ Plant height (cm) } \\
\hline & $0 \mathrm{ml} \mathrm{L} \mathbf{L}^{-1}$ & 134.67b & $116.32 a$ & 134.75b \\
\hline & $2 \mathrm{ml} \mathrm{L}^{-1}$ & 131.67a & 113.67a & 129.33ab \\
\hline & $4 \mathrm{ml} \mathrm{L}^{-1}$ & 131.33a & $113.27 a$ & 122.08a \\
\hline \multicolumn{5}{|l|}{ Test weight (g) } \\
\hline & $0 \mathrm{ml} \mathrm{L} \mathrm{L}^{-1}$ & $3.36 \mathrm{a}$ & $2.86 a$ & $3.14 a$ \\
\hline & $2 \mathrm{ml} \mathrm{L}^{-1}$ & $3.43 a$ & $3.11 b$ & $3.32 \mathrm{~b}$ \\
\hline & $4 \mathrm{ml} \mathrm{L}^{-1}$ & $3.46 a$ & 3.14b & 3.31b \\
\hline \multicolumn{5}{|l|}{ Grain Yield $\left(\mathrm{t} \mathrm{ha}^{-1}\right)$} \\
\hline & $0 \mathrm{ml} \mathrm{L}^{-1}$ & 2.23a & $2.22 a$ & 2.09a \\
\hline & $2 \mathrm{ml} \mathrm{L}^{-1}$ & $2.32 \mathrm{~b}$ & $2.19 a$ & $2.20 \mathrm{~b}$ \\
\hline & $4 \mathrm{ml} \mathrm{L}^{-1}$ & $2.43 b$ & $2.30 \mathrm{a}$ & $2.29 \mathrm{~b}$ \\
\hline \multicolumn{5}{|l|}{ Straw Yield (t ha $\left.{ }^{-1}\right)$} \\
\hline & $0 \mathrm{ml} \mathrm{L} \mathrm{L}^{-1}$ & $4.74 a$ & $3.60 \mathrm{a}$ & $4.51 b$ \\
\hline & $2 \mathrm{ml} \mathrm{L}^{-1}$ & $5.48 b$ & $3.76 a$ & 4.63a \\
\hline & $4 \mathrm{ml} \mathrm{L}^{-1}$ & $5.59 \mathrm{~b}$ & 3.63a & $5.32 b$ \\
\hline
\end{tabular}


Table.2 Effect of foliar silicic acid on Si content in straw, glume and grains and total uptake of $\mathrm{Si}$ in ragi genotypes

\begin{tabular}{|c|c|c|c|c|}
\hline \multirow[t]{2}{*}{ Parameters } & \multirow[t]{2}{*}{ Si levels } & \multicolumn{3}{|c|}{ Genotypes } \\
\hline & & GPU- 28 & GPU- 67 & K- 7 \\
\hline \multirow[t]{3}{*}{ Straw $(\%)$} & $0 \mathrm{ml} \mathrm{L}^{-1}$ & $1.80 \mathrm{a}$ & $1.49 a$ & $1.39 a$ \\
\hline & $2 \mathrm{ml} \mathrm{L}^{-1}$ & $1.94 a$ & $1.75 a$ & $1.75 a$ \\
\hline & $4 \mathrm{ml} \mathrm{L}^{-1}$ & 2.22ab & 2.07ab & 2.13ab \\
\hline \multicolumn{5}{|l|}{ Grain (\%) } \\
\hline & $0 \mathrm{ml} \mathrm{L} \mathrm{L}^{-1}$ & $0.30 \mathrm{a}$ & $0.32 a$ & $0.13 a$ \\
\hline & $2 \mathrm{ml} \mathrm{L}^{-1}$ & $0.38 \mathrm{a}$ & $0.36 \mathbf{a}$ & $0.22 a$ \\
\hline & $4 \mathrm{ml} \mathrm{L}^{-1}$ & $0.38 \mathbf{a}$ & $0.41 a$ & $0.26 a$ \\
\hline \multicolumn{5}{|l|}{ Glumes (\%) } \\
\hline & $0 \mathrm{ml} \mathrm{L}^{-1}$ & $2.02 a$ & $1.53 a$ & $1.37 \mathbf{a}$ \\
\hline & $2 \mathrm{ml} \mathrm{L}^{-1}$ & $2.23 b$ & $1.67 a$ & $1.77 b$ \\
\hline & $4 \mathrm{ml} \mathrm{L}^{-1}$ & 2.81c & $2.06 \mathrm{~b}$ & $2.47 \mathrm{c}$ \\
\hline \multicolumn{5}{|c|}{ Si Uptake (kg ha $\left.{ }^{-1}\right)$} \\
\hline & $0 \mathrm{ml} \mathrm{L} \mathrm{L}^{-1}$ & 103.58a & $68.12 a$ & 101.43a \\
\hline & $2 \mathrm{ml} \mathrm{L}^{-1}$ & $125.68 \mathrm{~b}$ & 86.33a & 113.97a \\
\hline & $4 \mathrm{ml} \mathrm{L}^{-1}$ & $159.19 \mathrm{c}$ & 105.87ab & $157.17 b$ \\
\hline
\end{tabular}

Table.3 Effect of foliar applied Silicic acid on nutrient content and uptake

\begin{tabular}{|c|c|c|c|c|c|c|c|c|c|c|}
\hline & \multirow[t]{2}{*}{ Si levels } & \multicolumn{3}{|c|}{ Grain (\%) } & \multicolumn{3}{|c|}{ Straw (\%) } & \multicolumn{3}{|c|}{ Uptake (kg ha $\left.{ }^{-1}\right)$} \\
\hline & & $\begin{array}{c}\text { GPU- } \\
28\end{array}$ & $\begin{array}{c}\text { GPU- } \\
67\end{array}$ & K- 7 & $\begin{array}{c}\text { GPU- } \\
28\end{array}$ & $\begin{array}{c}\text { GPU- } \\
67\end{array}$ & K- 7 & $\begin{array}{c}\text { GPU- } \\
28\end{array}$ & $\begin{array}{c}\text { GPU- } \\
67\end{array}$ & K- 7 \\
\hline \multirow[t]{3}{*}{ Phosphorus } & $0 \mathrm{ml} \mathrm{L} \mathbf{L}^{-1}$ & $0.34 a$ & $0.34 a$ & $0.35 a$ & $0.23 a$ & $0.28 \mathrm{a}$ & $0.33 a$ & $18.50 \mathrm{a}$ & 17.71a & 21.82a \\
\hline & $2 \mathrm{ml} \mathrm{L}^{-1}$ & $0.31 a$ & $0.35 a$ & $0.36 \mathrm{a}$ & $0.34 b$ & $0.33 b$ & $0.38 b$ & $26.84 b$ & 20.07ab & $24.69 b$ \\
\hline & $4 \mathrm{ml} \mathrm{L}^{-1}$ & $0.35 a$ & $0.33 a$ & $0.36 a$ & $0.38 \mathrm{c}$ & $0.38 \mathrm{c}$ & $0.38 b$ & $29.27 \mathrm{bc}$ & $21.89 \mathrm{~b}$ & $27.79 c$ \\
\hline \multicolumn{11}{|l|}{ Calcium } \\
\hline & $0 \mathrm{ml} \mathrm{L}^{-1}$ & $0.27 a$ & $0.34 a$ & $0.58 \mathrm{a}$ & $1.07 b$ & $0.55 a$ & $0.74 a$ & $86.36 a$ & $50.81 a$ & $71.50 \mathrm{a}$ \\
\hline & $2 \mathrm{ml} \mathrm{L}^{-1}$ & $0.45 a$ & $0.58 \mathrm{a}$ & $0.45 a$ & $0.87 a$ & $1.00 \mathrm{c}$ & $0.94 b$ & 91.24a & $74.55 b c$ & $81.76 b$ \\
\hline & $4 \mathrm{ml} \mathrm{L}^{-1}$ & $0.51 a$ & $0.38 \mathrm{a}$ & $0.51 a$ & $1.06 b$ & $0.87 b$ & $1.13 \mathrm{c}$ & $110.5 b$ & $65.33 b$ & $104.79 c$ \\
\hline
\end{tabular}




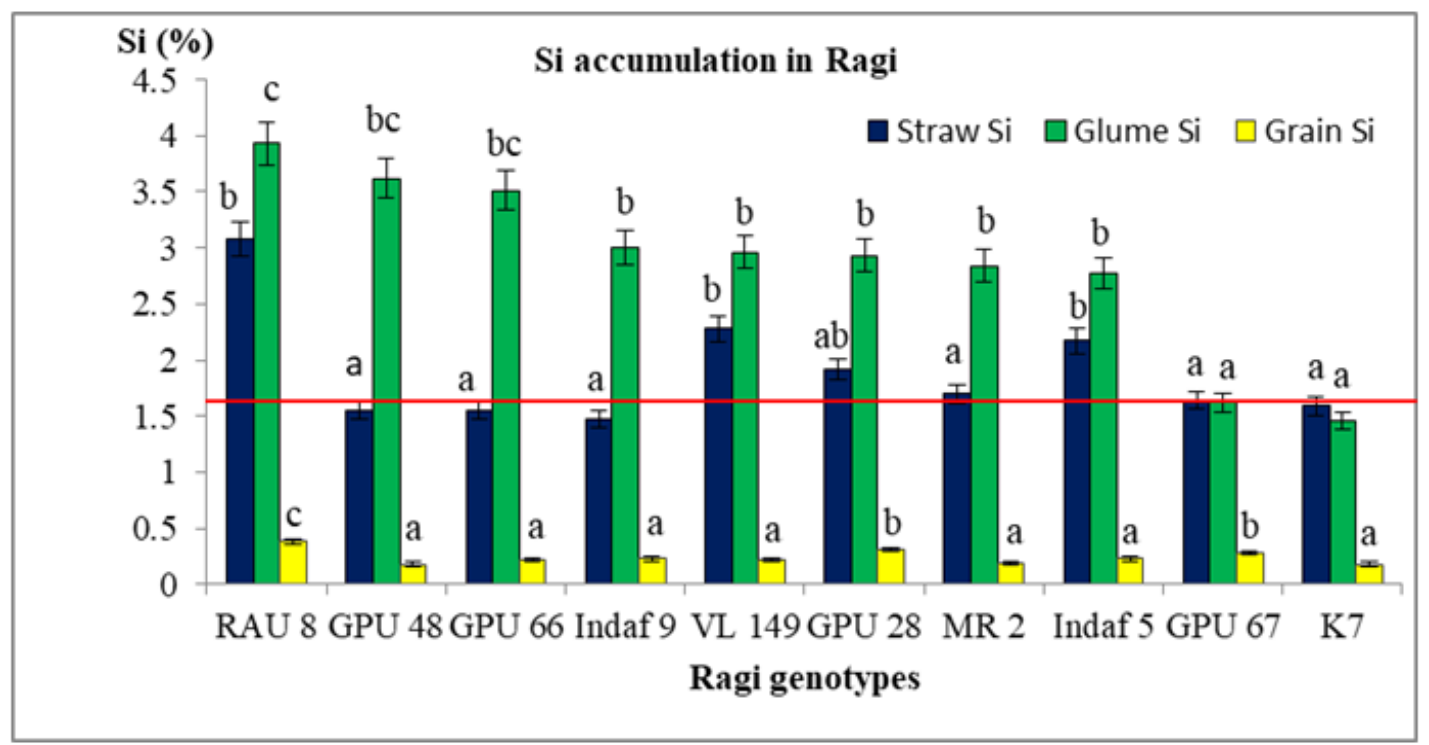

Fig.1 Si accumulation in straw, glumes and grains of ragi genotypes. Horizontal line represents the average Si content (1.6\%) in ragi. Values are means of three replicates. Means within a column followed by the same letter are not significantly different $(\mathrm{p}<0.05)$.

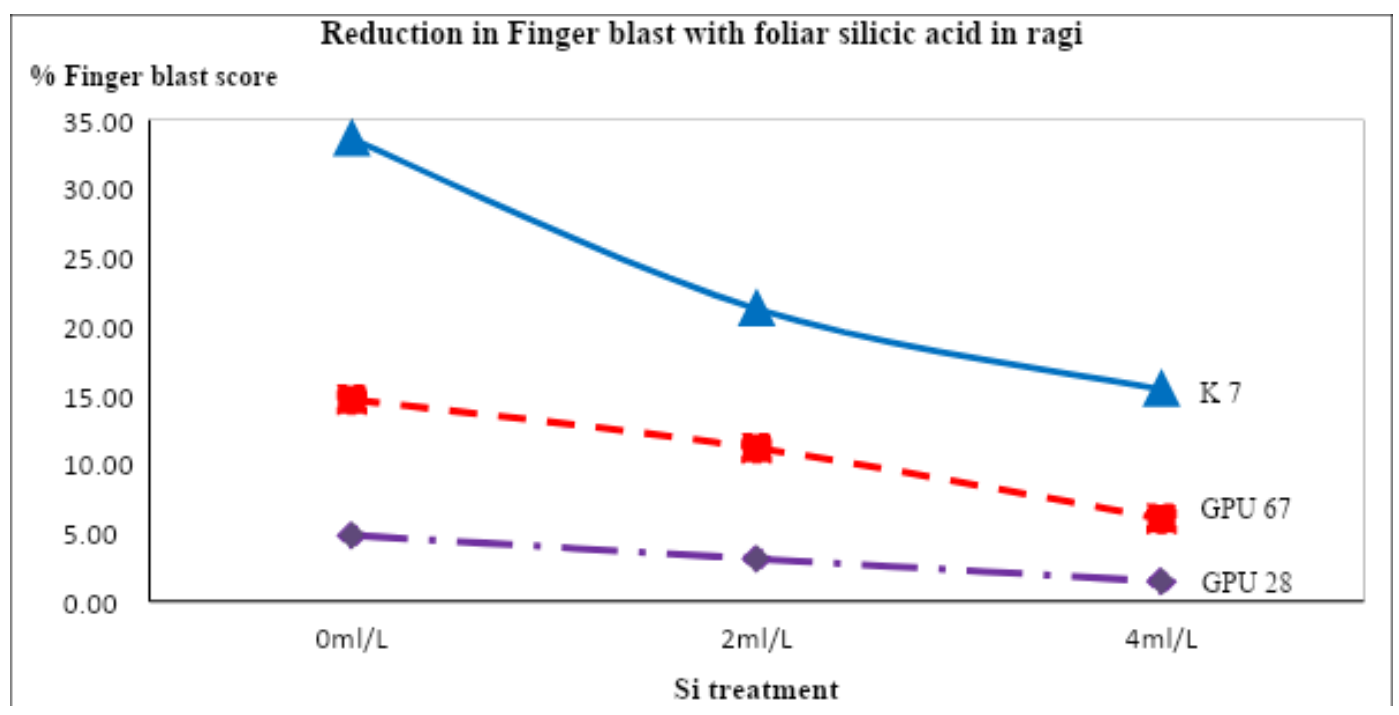

Fig.2 Effect of foliar silicic acid on the incidence of Finger blast in ragi

In this study $\mathrm{Si}$ content and varietal variation in its accumulation in Finger millet was documented for the first time. Ragi accumulated considerable amount of Si (1.67 $\%)$ and showed genotypic variation in $\mathrm{Si}$ accumulation. Irrespective of all the genotypes, the highest accumulation was found in glumes (1.5- $3.9 \%$ ) followed by straw (1.6- $3.1 \%$ ) and grains (0.18- $0.38 \%$ ).
It was observed that disease resistant varieties accumulated more $\mathrm{Si}$ in their aboveground biomass than susceptible varieties. Foliar application of silicic acid increased the uptake of $\mathrm{Si}, \mathrm{P}$ and $\mathrm{Ca}$ content and yield parameters like test weight, grain and straw yield. Foliar spray of silicic acid @ $4 \mathrm{ml} \mathrm{L}^{-1}$ was effective in improving crop yield, nutrient uptake and reduced blast disease incidence. 


\section{References}

Bélanger RR, Benhamou N, Menzies JG (2003) Cytological evidence of an active role of silicon in wheat resistance to powdery mildew (Blumeria graminis f. sp. tritici). Phytopath 93: 402-412.doi: 10.1094/PHYTO.2003.93.4.402.

Bent E (2014) Silicon solutions: Helping plants to help themselves. Sestante edizioni, Bergamo.

Bowen P, Menzies J, Ehret D et al., (1992) Soluble silicon sprays inhibit powdery mildew development on grape leaves. J Am Soc Hortic Sci 117: 906- 912.

Buck GB, Korndorfer GH, Coelho ANL (2008) Potassium silicate as foliar spray and rice blast control. J Plant Nutr 31: 231-237.doi: 10.1080/01904160701853704

Carver TLW, Zeyen RJ, Ahlstrand GG (1987) The relationship between insoluble silicon and success or failure of attempted primary penetration by powdery mildew (Erysiphegraminis) germlings on barley. Plant Physiol Plant Mol Pathol 31: 13348.doi:10.1016/0885-5765 (87)90012-9

Chetan S, Malleshi NG (2007) Finger millet polyphenols: Optimization of extraction and the effect of $\mathrm{pH}$ on their stability. Food Chem 105 (2): 862- 870.

Datnoff LE, Deren CW, Snyder GH (1997) Silicon fertilization for disease management of rice in Florida. Crop Prot 16: 525- 531.doi:10.1016/S02612194(97)00033-1

Deren CW (2001) Plant genotype, silicon concentration and silicon- related responses. In: DatnoffLE et al., (ed) Silicon in Agriculture. SaundersWB, Philadelphia, pp : 149- 158.

Epstein E (1994) The anomaly of siliconin plant biology. Proc Natl Acad Sci. USA, 91: 1117.

Epstein E (2001) Silicon in plants: Facts vs. concepts. In: Datnoff LE, Snyder GH and KorndorferGH (Coords.) Silicon in Agriculture. Elsevier, Amsterdam, Holand, pp:1-15.doi:10.1016/S0928-
3420(01)80005-7

Fawe A, Abou-Zaid M, Menzies JG, Belanger RR (1998) Silicon mediated accumulation of flavonoid phytoalexins in cucumber. Phytopath 88: 396- 401.doi: 10.1094/PHYTO.1998.88.5.396

Gallo JR, Furlani PR, Bataglia OC, Hiroce R (1974) Silicon content in grass and forage crops. Cienciae Cult 26:282-293.

Gong H, Chen K, Chen G et al., (2003) Effects of silicon on growth of wheat under drought. J Plant Nutri 26(5): 1055- 1063. doi:10.1081/PLN-120020075

Guével MH, Menzies JG, Bélanger RR (2007) Effect of root and foliar applications of soluble silicon on powdery mildew control and growth of wheat plants. Eur J Plant Pathol 119: 429- 436.DOI 10.1007/s10658-007-9181-1

Gupta A, Gupta HS (2013) Small millets. In: Prasad R (ed) Textbook of field crops production- foodgrain crops, Volume 1, ICAR, New Delhi, pp 226- 231

Hattori $\mathrm{T}$, Inanaga $\mathrm{S}$, Araki $\mathrm{H}$, An $\mathrm{P}$ et al., (2005) Application of silicon enhanced drought tolerance in Sorghum bicolor. Physio Plantarum 123:459-466

Hodson MJ, Sangster AG (1988) observations on the distribution of mineral elements in the leaf of wheat (Triticum aestivum L), with particular reference to silicon. Ann Bot 62:463-471.

Hodson MJ, White PJ, Mead A, Broadley MR (2005) Phylogenetic variation in the silicon composition of plants. Ann Bot 96:10271046

Islam A,Shaha R (1969) Effect of silicon on the chemical composition of rice plant. Plant soil 30: 446- 458.

Korndorfer GH, Pereira HS, Nolla A (2004) An'alise de sil'icio no solo, planta e fertilizante [Silicon analysis in soil, plant and fertilizers].Uberl`andia, Brazil, GPSi/ICIAG/UFU.

Kumari P, Sumathi L (2002) Effect of consumption of finger millet on hyperglycemia in non-insulin dependent diabetes mellitus (NIDDM) subjects. Plant Food Human Nutri 57 (3/4): 205- 213. 
Lux A, Luxova M, Hattori $\mathrm{T}$ et al., (2002)Silicification in sorghum (Sorghum bicolor) cultivars with different drought tolerance. Physiol Plantarum 115:8792.doi: 10.1034/j.13993054.2002.1150110.x

Ma JF, Higashitani A, Sato K, Takeda K (2003) Genotypic variation in silicon concentration of barley grain. Plant Soil249: 383- 387.doi: 10.1023/A:1022842421926

Ma JF, Miyake Y, Thakahashi E (2002) Silicon as a beneficial element for crop plants.In: Datnoff LE, Snyder GH, Korndorfer GH (ed) Silicon in Agriculture. Elsevier Science, The Netherlands, pp: 17- 39.

Ma JF, Nishmura K, Takahashi E (1989) Effect of silicon on the growth of rice plant at different growth stages. Soil Sci Plant Nutr 35: $347-$ 356.doi:10.1080/00380768.1989.10434768

Marschner H (1995) Mineral nutrition of higher plants.Academic press, Harcout Brace Company Puplisers, London.

Narayanaswamy C, Prakash NB (2009) Calibration and characterization of plant available soil silicon in rice soils of South India. J Plant Nutr 32(8): 1237- 1254.doi: 10.1080/01904160903005970

Prakash NB, Chandrashekar N, Mahendra C et al., (2011) Effect of foliar spray of soluble silicic acid on growth and yieldParameters of wetland rice in hilly and coastal zone soils of Karnataka, South India. J Plant
Nutr 34(12): 1883-1893. doi: 10.1080/01904167.2011.600414

Richmond KE, Sussman M, (2003) Got silicon? The non-essential beneficial plant nutrient. Current Opinion in Plant Bioly 6: 268272.doi:10.1016/S1369-5266 (03)00041-4

Rodrigues FA, Benhamou N, Datnoff LE et al., (2003) Ultrastructural and cytochemical aspects of silicon-mediated rice blast resistance. Phytopath 93: 535-546. doi:10.1094/PHYTO.2003.93.5.535

Rodrigues FA, Mcnally DJ, Datnoff LE et al., (2004) Silicon enhances the accumulation of diterpenoidphytoalexins in rice: a potential mechanism for blast resistance. Phytopath 94: 177-83.doi: 10.1094/PHYTO.2004.94.2.177

Singh K, Singh R, Singh JP et al., (2006) Effect of level and time of silicon application on growth, yield and its uptake by rice (Oryza sativa). Indian J Agric Sci 76 (7): 410- 413.

Takahashi E, Ma JF, Miyake Y (1990) The possibility of silicon as an essential element for higher plants. J Exp Bot 56 (414): 12551261.

Winslow MD, Okada K, Correa-Victoria F (1997) Silicon deficiency and the adaptation of tropical rice ecotypes. Plant Soil 188: 239-248.doi: 10.1023/A:1004298817861

Yamaji N, Mitatni N, Ma JF (2008) Transporter regulating silicon distribution in rice shoots, Plant Cell 20: 1381- 1389. DOI: $10.1105 /$ tpc. 108.059311

\section{How to cite this article:}

Sandhya, T. S., N. B. Prakash, A. Nagaraja and Nanja Reddy, Y. A. 2020. Effect of Foliar Silicic Acid on Growth, Nutrient Uptake and Blast Disease Resistance of Finger Millet (Eleusine coracana (L.) Gaertn.). Int.J.Curr.Microbiol.App.Sci. 9(04): 2111-2121. doi: https://doi.org/10.20546/ijcmas.2020.904.254 